\title{
مشكلة التعليم في الوطن العربي العراق انموذجا)
}

م.د. فيصل محمد عليوي التميمي

قسم الاجتماع - كلية الاداب - فحمد علوية تكريت

تأخذ مشكلة التعليم في عالمنا اليوم حيزا كبيرا من اهتمام كل دوله , وترصد لها نسبة لا يستهان بها مـن الأموال والجهـود والكفـاءات وميزانيـة لاتقل عن ميزانيـة تنظيم الجهيش أو التمـوين أو المواصـات أو سـائر شوؤن الدولة .

ويرجع ذلك إلى أن الدول المعاصرة أخـذت على عاتقها أن تعلم كل أبنـاء الشعب , وان تيئ لهم كل أسباب التعليم مـن مـدارس ومعلمـين ومعلمات وكتـب وتختـار لهم العلوم والمنـاهج ضمن ماتاخـذه الدولة المعاصرة على عاتقها من تنظيم كل مايحتاجه الشعب وتوفيره , كالعمل والأمن والازدهار والحماية والحرية والكرامة والغذاء والكساء وحرية التجارة وحرية العمل ...الخ. كل هذه الأمور تبنى بالارتكاز على قواعد وأسس التربية والتعليم , فالتربية تنمي الثروة البشرية وهذه الثروة إذا وجهت توجيها صالحا حققت الأمة في أجيالها حب العمل وإتقانه واستنباط ثروات الأرض بأسلوب تقني يعطي أفضل إنتاج وأعظم كميه بأقل جهد وأسرع وقت وتكلفه. وبالتعليم والتربية تستطيع الدول تحقيق الاستقلال الثقافي والاقتصادي والتحرر من الظلم والعبودية والطغيان وتخليص الشعوب من التبعية الفكرية والثقافية والسياسية .إلا إننا ورغم التطورات الهائلة في مجال العلوم والتكنولوجيا وما وصلت إليه الشعوب مـن تكنولوجيا المعلومات والفضـاء والطب , إلا إننا نرى تدلي مستوى التعليم في الوطن العربي وعندما ننظر في امر هـ ونفكر في منجزاته وفي علاقته بمجتمع المعرفة, نتخطى عتبـة التحديات المطروحة على انظمهة التربية والتعليم في اغلب البلـدان العربية مـن قبيـل محو الاميـة, والموائمـة بـين النظام التعليمي وخطط التنمية وتعليم العلوم, وعلاقة التعليم بالسوق, وعلاقته بالبطالة والعمل. حيث تواجه اغلب البلدان

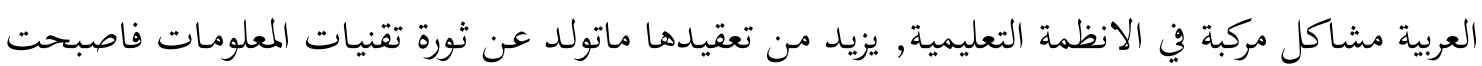
المطالب مضاعفة واختلطت فيها تحديات الامس بتحديات اليوم والغد .والعراق احد تلك البلدان العربية الذي يشـل ابنـاءه ثروته الحقيقيـة , ويتميز المجتمع العراقي بارتفـاع نسبة الشباب فيه ويشكل العنصـر النسوي اكثر من نصف المجتمع العراقي, واثرت الحروب والنزاعات سلبا على العراق, وقد دفع ثمنا اجتماعيا

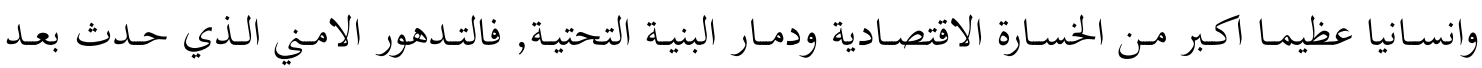
الاهيار المؤسساتي الشـامل فرض البطالة على الاف المواطنين, مـا ادى الى انتشار دائرة الفقر فضلا عن 
الدمار الذي لحق بالنظام التعليمي الذي خلف اعداد هائلة من الاميين وانتشار الجهل والتخلف .فالعراق اذن بحاجـة المى عمليـة تمكـن واستثمار المـوارد البشـية وتسـخير المـوارد الاقتصـادية لاجـل اصـلاح النظـام التعليمي المتدهور . n

\section{المبحث الاول:منهج البحث \\ 1}

تمثل العلاقة بين مستويات التعليم في اي بلد وتطوره علاقة اشكالية , فالتطور والتنمية لايمكن ان تتحقق دون وجود بجتمع متعلم يمثل عمادها الاساس ومادتها الاولية. ان انخفاض مستوى التعليم وازدياد نسب الامية لانتوقع زوالها والقضاء عليها إلا مـ خلال تمكين جميع افراد المجتمع من الحصول على وسائل وفرص العيش الحر الكريم وعلى راس تلك الاولويات هو التعليم. ان هذه العلاقة الجدلية تتطلب الوقوف على حيثياتا وتحليلها واسسها وفهم وتحديد التداعيات التي تترتب على الاخفاق في معالجة الامية وفي رفع مستوى التعليم, وتقف الامية عقبة تعوق تقدم الفرد وتعطل تطور المجتمع في مختلف النواحي وتقف حجر عثرة امـام تحقيق اهـداف الفرد والمجتمع وقد باتت الامية وتـدني مستويات التعليم في البلدان العربية تمثل مشكلة حقيقية بسبب التغيرات والتطورات الاجتماعية الحديثة والسريعة والتي تجعل حياة الفرد الامي في المجتمع المعاصر شديدة الصعوبة, وليس الامي فحسب بل حتى ان الذي يحصل على التعليم وبصورة غبر موفقـة وغير تربوية, وهنـا تبرز المشكلات التربوية والاقتصـادية والثقافية والسياسية المستعصية. لذا يمكننا ان نلخص مشكلة البحث بعض التساؤلات:-ماهي مستويات التعليم والامية في البلدان العربية . - كيف يمكننا معالجة مشكلات التعليم أو تقليصها أو الحد منها؟ - كيف يمكن ردم فجوة النوع أو الحد من توسعها ؟ - كيف يمكن الحد من تفاقم مشكلة الامية في البلدان العبية والعراق بالذات؟

2. 2 2 2 2 2

يهدف البحث إلى التعرف على مستوى التعليم والامية في البلدان العربية, ونسبتها في العراق وطبيعة علاقة مستوى التعليم, بنسبة اعداد المدرسين والمعلمين إلى اعداد التلاميذ والطلاب, وبين نسب اعداد المدارس 
أو المؤسسات التربوية إلى اعداد الطلاب , وكذلك بين عدد السكان وازدياد نسبة الامية تبعا لتقدم السنين وبمقياس عكسي. 3. اهمية البحث

تاتي اهمية البحث من واقع التغيرات والازمات التي مر بها العراق بسبب الحروب والحصار والاحتلال ومنها ازمات اقتصادية وسياسات عسكرية خاطئة, وانعدام الامن وعدم الاستقرار السياسي مما ادى إلى الخفاض مستوى التعليم وتفشي ظاهرة الامية في المجتمع العراقي والتي اصبحت من اهم التحديات التي واجهتها الحكومة. والامية في العراق تعد من المشاكل الرئيسية التي تحول بين فئة كبيرة من المجتمع العراقي والثقافة المعبرة عـن امـالمم وطموحـاتم , ويشكل محوهـا هـو حقـا اصيلا مـن حقـوق الانسـان واداة لتعزيز التنميـة البشرية والاجتماعية والاقتصادية. المبحث الثالي: مشكلات التعليم في الوطن العربي خطت البلدان العربية خطوات واسعة في التعليم, وبخاصة منذ منتصف القرن العشرين. ومع ذلك, فان الانجاز العلمي في البلدان العربية بمجمله, حتى بالمعايير التقليدية, مايزال متواضعا اذا ماقورن بالانجازات في اماكن اخرى في العالم, حتى في البلدان النامية1 رغـم كل التطور الذي حصل في مجـال التعليم في البلـدان العربيـة والخطـوات الواسعة في هـذا المجال بعـد منتصف القرن العشـين , الا ان هنـاك معوقات كثيرة في تلك البلدان سـواء مـن حيث نوعية التعليم او المنـاهج واسـاليب التعليم ومسن حيـث الدراسـة النظامية والفـروق في مستويات التعليم ....الخ وبهـذا فتـد اصبحت مشكلة التعليم في البلدان العربية خطيرة جدا , حتى على مستوى الاميين , لذا فان التدهور في هذا المجال قد فاق التوقعات , لاسيما توقع عالم الاجتماع (انتوبي غدنز) , إذ توقع إختفاء الامية بين الذكور قبل فاية الربع الاول من القرن الحادي والعشرين وبين النساء عام (2040 ) وبالرغم من ان اول حروف الكتابة والتعلم اكتشفت في العراق قبل الميلاد, ورغم من ان العراق الحديث يعتبر من اوائل الدول التي اهتمت بالتربية والتعليم منذ احتلال الدولة العثمانية له , الم الاحتلال البريطاني والحكومات المتعاقبة بعـد ذلك الا اننـا نلاحظ ان التعليم في العراق يعـاني مـ مشكلات بنيويـة ووظيفيـة وجـدت في صـلب المؤسسة التعليمية وان تغيرت نسبيا لكنها ظلت واضحة والى حد كبير حتى يومنا هذا. ومنها على سبيل المثال لا الحصر التفاوت في إشباع الحاجة إلى التعليم مابين الذكور والإناث ، وبين سكان الريف والحضر ، 
إلى جانب مدى كفاءة المعلم والإدارة التعليمية ، ونوعية التعليم. ومنها الوعي بأهمية التعليم ، وخصوصاً تعليم الإناث. و وما زاد من تعقيد المشكلات توجه الحكومة نحو تسييس التعليم مما اثر على جميع عناصره من مقررات وسياسات كما يشير البنك الدولي²

لـذا فيمكننـا القـول ان التعليم في البلـان العربيـة يعـاني مـن مشـاكل ابديـة مـن عـدة نـواحي, مـن حيـث الالتحاق بالتعليم النظامي او من حيث الانفاق على التعليم او من حيث نوعية التعليم والاخطر من ذلك هو تسييس التعليم والتلاعب في المناهج واساليب التعليم .فضالا عن تفاقم مشكلة الامية والتفاوت في مستوى التعليم بين الذكور والاناث. وسناتي الى التعريف بذلك لاحقا. ولو اخذنا على سبيل المثال فروق الحالة التعليمية بين الريف والحضر في جمهورية مصر العربية, نرى ان عدد الاميين في حضر وريف الجمهورية يبلغ حسوالي 15مليون فرد وبنسبة 56\% مـن جملة سكان الجمهورية المصريين(10سـنوات فـاكثر). في الريف يتركز حوالي 68\% وفي الحضر حوالي 31\% من جملة الاميين في الحضر والريف.

اما اعداد من يقرأ ويكتب في ريف وحضر مصر فهو حوالي 6 مليون فرد بنسبة 20\% من جملة السكان

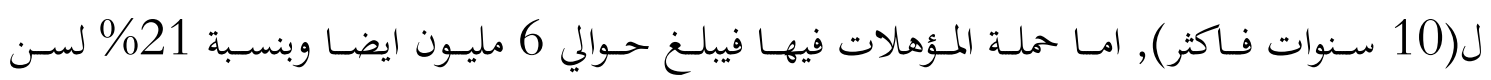
3. (10)

ومهما بلغت البلدان العربية من جهاد في سبيل رفع المستوى التعليمي إلا اها تبقى خارج مستوى الطموح

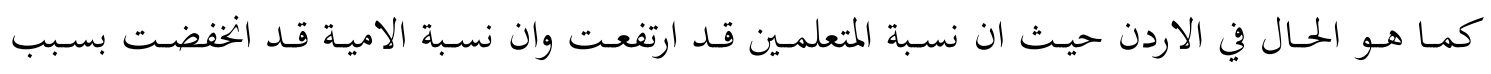
الانتشار الواسع لمدارس البنين والبنات بعد الربع الاخير من القرن العشرين, إلا ان هذا الجانب مازال يحتاج إلى بذل جهود كبيرة للقضاء على الامية بين صفوف الشباب 4 وسنعرج بايجاز على مستوى التعليم في البلدان العربية من حيث الالتحاق بالتعليم النظامي والانفاق على بلى التعليم في العـالم العربي وموضوع على قدر مـن الاهمية وهـو القـدرة على تحمل التكاليف وجـودة ونوعية التعليم ومنـاهج واسـاليب التعليم والزاميـة التعليم, وتشـير بيـانات الالتحـاق بمستويات التعليم الثلاثـة في البلدان العربية قصة تطور كمي مطرد. فقد ارتفع عدد الطلاب الملتحقين بمستويات التعليم الثلاثة من 31

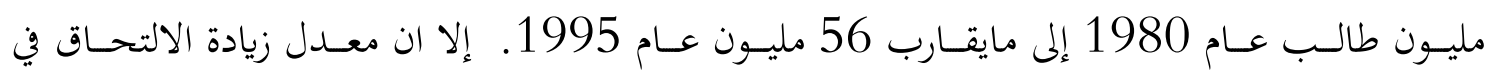
مستويات التعليم الثلاثة تباطأ اثناء التسعينات بالمقارنة مع معدله في الثمانينات. 
وتشير البيانات المتوافرة عن الالتحاق بالمدارس على المستوى الاول من التعليم النظامي إلى ان العالم العربي قد قصر حتى الان عن استيعاب الافواج الجلديدة مـ المواطنين العرب ـ ويزداد القصور في حالة البنات, سواء كانت بالمقارنة مع البلدان النامية أو مع العالم بمجمله. اما من حيث الانفاق على التعليم في البلدان العببية فقد انخفض الابفاق على كل فرد بالمقارنة مع البلدان الصناعية من 20\% مماكانت تنفقه البلدان الصناعية عام 1980 إلى 10\% في منتصف التسعينات . وهنالـك خطـر واضـح مسن انقسـام نظم التعلـيم في البلـدان العربيـة إلى قسـمين لايمتـــ احــهما للاخـــ بصلة:تعليم خاص مكلف جـا تتمتع به الاقلية الميسورة الحال, وتعليم حكومي سيء النوعية للاغلبية. اضـافة لذلك تنـاقص الكفـاءة الداخلية للتعليم في العالم العربي مـا يؤدي إلى ارتفاع معدلات الرسوب في مختلف المراحل إلا ان المشكلة الاخطر تكمسن في جودة التعليم, حيث تردي نوعيتة. اضـافة إلى عزوف الكثير من الشرائح الاجتماعية مـ ارسال ابنائهم إلى القطاع التعليمي الرسمي وارسالهم إلى القطاع الخناص 5 بسبب قصور النظام التعليمي الرسمي

اما من حيث المناهج , رغم ان كثير من البلدان العربية لايختلف منهجها الدراسي عن بلدان العالم الااننا نلاحظ ان موضوع التلاعب بالمناهج اصبح سمة بارزة للعديد من البلدان العربية وفقا لاهواء السلطة . بل اصبح تغيير المناهج مرتبط بتغيير بعض الحكومات. وان تاثير مايسمى بالربيع العربي ليس بعيداعن تغيير مناهجنا الدراسية. والادهى والابعد من ذلك اصبح ليس بمقدور السلطة تغيير المنـاهج بل اصبح وزير التربية أو التعليم بمقدوره ان يغير المناهج حتى ولو إلى ان تنتهي فترة ولايته. اما الوزير اللاحق فسيقوم بنفس لتسير المهمة من تغيير المناهج واستبدالها, طبقا لرغبات حزبه أو طائفته.

\section{1.تجربة جمهورية مصر العربية في مجال محو الامية}

تعتبر مشكلة الامية في مصر هي مشكاة مزمنة ومعقدة لاترجع إلى سبب وانما إلى اسباب متعلددة (تاريكية, اجتماعية, اقتصادية, تربوية, ....الخ) ويتاثر تقدير حجم الامية في مصر بعدة مشاكل اهمها قلة البيانات وعدم دقتها وتعدد الاجهزة المسوؤلة عن جمع البيانات والمعلومات عن الامية ـ وتعتبر الامية في مصر من المشاكل التي تعوق برامج الدولة للتنمية والاصلاح فقد بلغت نسبة المتعلمين في مصر حسب تقدير الامم 
المتحدة للتنمية البشرية لعام 2006 (41,4\%) للبالغين 15 عام فاكثر و(84,9\%) للشباب من 15 . 24 عام 24 ووفقا للاحصائيات الرسمية وغير الرسمية ان نسبة الامية في مصر قد الخفضت خلال الثلاثين عاما الاخيرة بدرجـة كبـيرة حسين اوضـحت نتـائج التعـدادات الاربعـة الاخـيرة 1976 , 1986 , 1996 , 1966

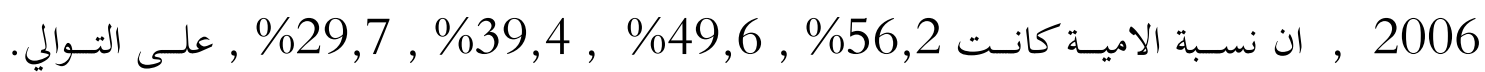
وذلك مـن خلال صدور قرار برقم 100 في 1944 ثم قرار رقم 8 في 1998 قانون الهيئة العامة لتعليم

إلا ان الاسباب التي ادت إلى عدم تحقيق الخطط التي وضعت لخو الامية هي:-7 أ.عدم وجود مكون لزيادة الدافعية لدى الاميين للالتحاق بفصول محو الامية. ب.عدم تحديد ادوار للجهات المشاركة في تنفيذ الخطة وترك تحديد الادوار لمراحل لاحقة. ت.نقص الاعتمادات المالية التي تم تخصيصها لتحقيق الخطة. ث.ضعف المشاركة الشعبية والتنفيذية. ج.ضعف المكون المعلوماتي الخاص بقواعد البيانات عن الاميين. وللتصدي لمشكلة محو الامية فيجب العمل بالاتي:أ.تبني سياسة اعلامية وتسويقية مستنيرة ومستمرة ب.ابتكار اساليب ووسائل تعليمية تتلائم مع المتطلبات والظروف المختلفة لمكونات الفئة المستهدفة. ت.تطوير مستمر للبرامج والمناهج واتاحة الفرص المتعددة والمتنوعة للتعليم المستمر. ث.مواصلة التعلم للمتحررين من الامية. ج.توفير نظام معلومات متطور للتخطيط ومراقبة الاداء. 2.عوامل انتشار الامية في الوطن العربي

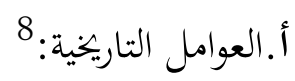

ساهمت سيطرة الاستعمار على اجزاء كبيرة من الوطن العربي في ظهور مشكلة الامية واستشرائها, لان المستعمرين ادركوا ان الامة الجاهلة ضعيفة لاحول لها ولارادة, ومن السهل السيطرة عليها, وهنب ثرواقا, فراحوا يمنعون نشر التعليم, ويضعون القيود عليه, ويعيقون مسيرته, ويوسعون منابع الامية. كما ان سيطرة 
الاستعمار ادت إلى اضعاف النظام التعليمي القائم واستبداله بنظام مستورد يخدم اهدافه, ويكرس التبعية له, ومن ثم سقوط كثير من العرب صغارا وكبارا في الجهل والامية . ب.العوامل الاقتصادية

على الرغم من الثروات الهائلة التي منحها الله تعالى للوطن العربي, فان الاوضاع الاقتصادية في كثير مـن الدول العربية لاتزال متردية, ولايزال الفقر ينهشها. وأسباب ذلك كثيرة منها سوء توزيع الثروة, والتزايد السكاني, وضعف الانتـاج, وزيادة الاستهالك, واخفـاق كثير مـن المشـروعات الزراعيـة والصـناعية وسـوء الادارة, وضـفف الاسـتقرار السياسي, وتـدني التكامل والتنسـيق بـين الـدول العربيـة, ونقـص الاسـتقلال والسيادة,

ت. العوامل السياسية9 لقد ساهمت بعض المشكلات ذات الطابع السياسي في نشر الامية في الوطن العربي ومنهـا :ضعف الاسـتقرار السياسي في كثير كثير مـن الـدول العربيـة جعـل انظمتهـا التربويـة كثيرة التغـير

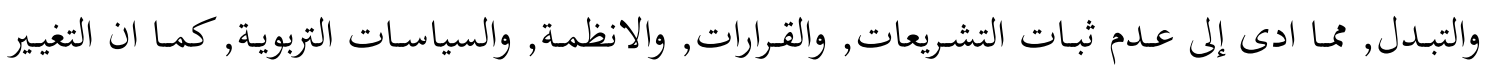
المستمر لمعظم وزراء التربية والتعليم العرب, وتعمد بعضهم هدم والغاء مابناه اسلافهم وجعل المشكلة اكثر صعوبة, واشد تفاقما ث. ثلعوامل الاجتماعية ان بعض العادات والتقاليد والافكار, والقيم الاجتماعية الخاطئة في الوطن العربي, كانت من الاسباب التي اوجدت مشكلة الامية, وزادتا حدة وتعقيدا فعلى سبيل المثال لايزال هناك اعتقاد لدى كثيرين بعدم اهمية تعليم الفتيـات, ولذذلك استفحلت الاميـة بـين الاناث مـن سن 15 عامـا, فـاكثر حتى وصلت في العـام 1980 إلى( 73,5\%) وان البعض اسبغ على الاعتقاد بعدم ضرورة التعليم للاناث طابعا دينيا بالرغم من ان الاسلام جعل العلم فريضة على كل مسلم ومسلمة .

$$
\text { ج.العوامل الجغرافية }
$$
ان توزيع المشروعات والميزانيات التربوية والتعليمية في الوطن العربي يخضع في بعض الاحيان لاسس ومعايير جغرافية, فالاهتمام ينصب اساسا على العواصم والمدن الكبرى على حساب مناطق الريف والبادية, التي 
في العـادة تعـاني مـن سوء توزيـع الخـدمات التربويـة والتعليميـة الذي ياخـذ شكل غيـاب المـارس, ونقصص الامكانات والتسهيلات والمرافق التعليمية, وقلة المعلمين, وضعف قدراهم وغيرها, الشيء الذي يؤدي إلى حرمان تلك المناطق من حقها في التعليم. ح. العوامل السكانية من الملامح الرئيسة للوطن العربي, الزيادة المطردة في سكانه, وعندما لايرافق الزيادة السكانية تخطيط تربوي سليم وبعيد المدى, تنتج مشكلات كثيرة وخطيرة منها انتشار الامية بين السكان, كما هو الحال فعلا في الوطن العربي على وجه العموم وفي العراق على وجه الخصوص وخاصة في الاونة الاخيرة . خ.العوامل الثقافية ان تدني المستوى الثقافي لكثير من الاباء والامهات, جعلهم اقل اندفاعا لتعليم ابنائهم وبناقم, مـازاد مـن نطاق الامية وانتشارها, لان قلة وعي اولياء الامور باهمية التعليم تنعكس سلبا على ابنائهم وبناقم, ويقلل مـن حصـولم على فرص الذهاب إلى المدرسـة, وقـد اظهرت نتـائج احـدى الدراسـات ان (16\%) مـن الدارسين في مدارس محو الامية ومراكزها في احدى الدول العربية, ولم يلتحقوا في المدارس عندما كانوا في سن التعليم الالزامي, لان اولياء امورهم لم يقدروا اهمية التعليم, ونظروا إليه بوصفه نوعا من انواع الترف, واضاعة الوقت . د. العوامل التعليمية

ان النظام التعليمي السائد في الوطن العربي مسؤول جزئيا عن مشكلة الامية من عدة وجوه منها, هناك نسبة عالية من الاطفال العرب هم في سن التمدرس لايجدون لمم مكانة في التعليم الابتدائي, فيصبحون, رصيدا متجددا من الاميين يضاف سنويا, ضعف ارتباط نظام التعليم السائد في الوطن العربي بالحياة ساهم

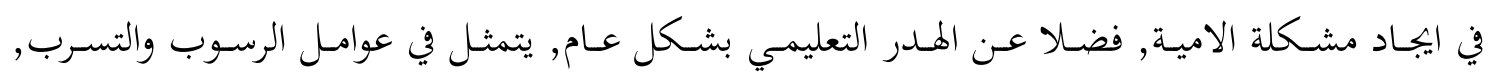
والاحباط, والمستويات العلمية المتدنية, مازاد من تفاقم مشكلة الامية . تلك العوامل وغيرها ادت إلى تفـاقم مشكلة الامية في الوطن العربي والى تغيب التنمية الحقيقية, وتحقيق مستويات متقدمة من التنمية.. فلا وجود للتنمية مع وجود الامية فهما قطبان متنافران لذلك لابد من القضاء على الامية التي تقف حـاجزا امـام التنمية, وبات ضـرورة لابـد منها, والنظر إلى الاميـة على اهـا

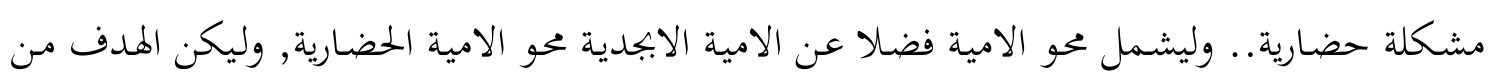
محو الامية هو تحقيق تنمية بشرية فضلا عن القضاء على التخلف بجميع اشكاله. 
ان محو الاميـة يشكل نـواة التعليم الاساسي للجميع, وهو عامل ضـروري للقضـاء على الفقر , وخفض معدلات وفيات الاطفال, والحد من النمو السكاني, وتحيق المساواة بين الجنسين, وضمان التنمية المستدامة والسام والديمقراطية.

$$
\begin{aligned}
& \text { المبحث الثالث: مشكالات التعليم في العراق } \\
& \text { 1 .تاريخ التعليم في العراق }
\end{aligned}
$$

لايستطيع اي باحـث مهمـاكانت درايته بالتـاريخ ان يخوض بموضوع التعليم في العـاق بـدون تحديد فترة زمنية. وهنا لابد ان نطرح عدة اسئلة منها, هل كانت هناك مدارس حقيقية, وهل التلميذ والمعلم في العراق القديم شبه للتلاميذ والمعلمين اليوم من ناحية طرق التعليم. هذه الاسئلة سوف نجيب عليها من خلال الاطلاع على سير العمليـة التعليمية في العراق القـديم والتي سبقت العالم في تقـديم اعظم اختراع إلا وهو

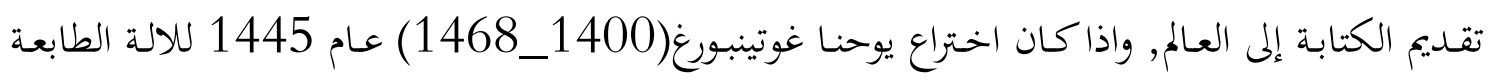

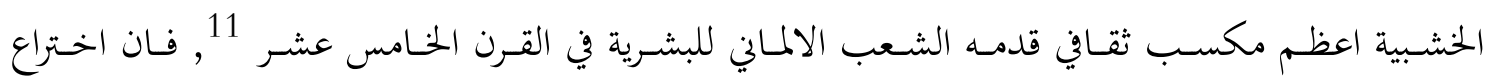

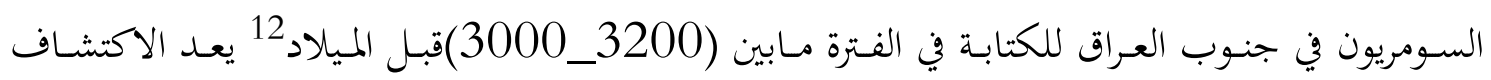
الاكبر على مر التاريخ لانه البذرة الاولى في مراحل الرقي الانساني ثم مواصلة التعليم منذ ذلك التاريخ إلى هذا اليوم الذي وصلت به الامم إلى التقدم والرقي. ولمعرفـة كيف كانـت المدرسـة في العـراق القـديم؟ يجيـب : اي. أي. سـبيزر , صـاحب كتـاب حضـارة وادي الرافدين, مترجم للعربية: كان نشوء المدرسة في بلاد وادي الرافدين نسحة مباشرة لاختراع الكتابة المسمارية التي تعد ابرز مااسهمت به بلاد سومر حيث صارت الكتابة تدرس تدريسا منتظما, وقد بلغ عدد الكتبة

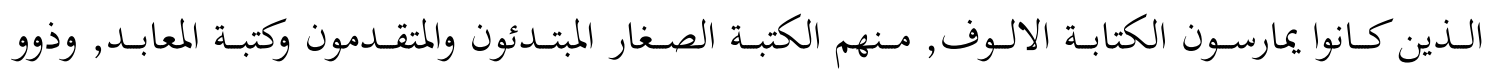
التخصص العالي وكبار مـوظفي الدولة, كانوا يتلقـون جميع فروع المعرفة في زمافم, وكانت المدرسـة مركز

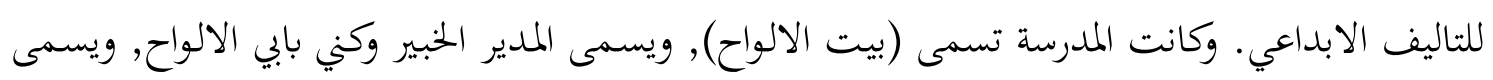
التلميذ (ابن بيت الالواح), وللمعلم مساعد من التلاميذ الكبار وكان المعلمون مختصين بتدريس موضوعات خاصة كاللغة السومرية والرياضيات, ويتكون منهج الدراسة من قسمين, الاول شبيه بالعلمي قائم على ملى

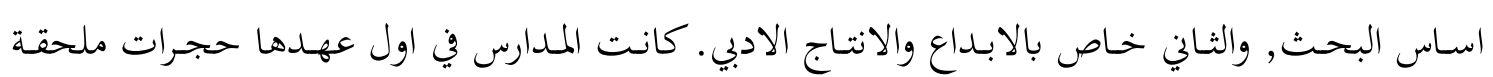
بالمعابد ثم استقلت في بيوت خاصة وليس في معابد 13 
خلال الفترة المظلمة المظلمة (فترة الاحتلال العثماني) كانت القيادة الشعبية والروحية للسكان بيد الوجهاء

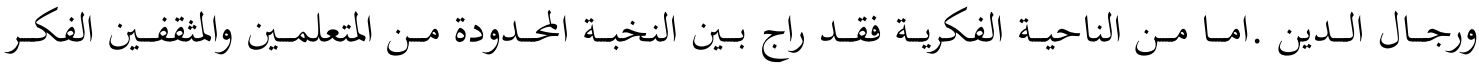
الارسطي_الافلاطوين القـائم على المثاليـة الجلدلية وصـياغة افتراضـات عامـة مـع القناعـة بصحتها المطلقـة ودعوة الناس عن طريق الوعظ الخطابي إلى الاخذ بها دون ان ترتبط بواقع الحياة العملية أو تتوفر لها اسباب تنفيذها.

امـا نظام التعليم في العراق فتركزت في نوعين مـن المؤسسات التعليمية:اولها مـدارس دينية وجدات في كافة انحاء العراق. وكانت ملحقة بجوامع ومساجد كل من الطائفتين الاسلاميتين الرئيسيتين. عرفت عند السنة ب (الكتاتيب أو التكية) وعند الشيعة ب (الملال أو المكتب). واشتمل التعليم في هذه المدارس على دراسة القران واللغة العربية والفكر الديني.. وثانيهما المعاهد الحكومية في بغداد واسطنبول حيث اختصت بتدريس العلـوم العصـرية, بالاضـافة إلى المـدارس العسـكرية. وكـان للطالـب الخيـار في الانتقـال مـن الكتاتيـب إلى

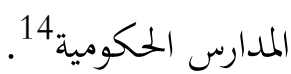

ومـع وصـول مـدحت باشـا الـوالي العثمـاني إلمفعـم بالقـوة والنشـاط إلى بغـداد واليـا عـام 1869تم تنفيـذ اصـلاحات عديـدة في البلاد ومنهـا التعليم حيـث تم تاسـيس مطبعـة ونشـر اول جريـدة رسميـة (الزوراء), وتاسيس عدد من المؤسسات التعليمية,ومع ازدياد فرص الشباب في الاقاليم لتلقي العلم الحديث والتدرب امـا كمـوظفين أو كمـوظفين أو كضـباط عسـكريين, تاثر هـؤلاء بالتيـارات الفكريـة التي كانـت سـائدة في اسطنبول وفي الولايات على السواء بين الاوساط المتنامية للموظفين المثقفين واصحاب المهن. فتم في بغداد افتــاح عـدد مـن المؤسســات التعليميـة الحكوميـة منــ عـام 1869 1 ابرزهــا مدرسـتي الرشـيدية المدنيـة والعسكرية,والتحقت اعداد متزايدة من الشباب بكلية الحقوق أو بالكلية الحربية في اسطنبول 15 وبقيت المـدارس الرشـية سقيمة التدريس وليس فيها كادر تدريسي متفوق ولكنها كانت منتظمة اكثر وكانت وظيفة هذه المدارس اعداد وتخريج ضباط الجيش الذين يخدمون في الدولة العثمانية16 وانشات الدولة العثمانية مدارس عسكرية, رشدية واعدادية, وتعهدت الحكومة بتسفير المتخرجين منهم في كل عـام إلى اسطنبول وبادخـالهم في المعاهد العسكرية هناك, وكان نصيب بغداد مـن المدارس العسكرية

$$
\text { اكبر من نصيب الولايات العثملنية الاخرى } 17 .
$$

وفي عـام 1881 تخرجـت في بغـداد الدفعـة الاولى مـن تلاميذ الاعداديـة العسكرية, وكـان عـدهم (13) ولاجـل اكمـال تحصـيلهم الدراسي ارسـلوا إلى مكتـب الحربيـة باسطنبول. ان نقـل التلاميـذ إلى اسـنبول 
وادخـالهم في المـدارس العالية على حسـاب الحكومـة حفز الكثير مـن التلاميذ على الرغبـة في الدخول في المـدارس العسـكرية, وكـان المترفـين في العــاق يستيكفون ان يـدخلوا ابنـائهم في المــارس العسـكرية لاهـم يفضلون ادخالهم في المدارس الملكية ثم يرسلوفم بعد التخرج إلى اسطنبول ليدخلوا على حسابهم معاهـد

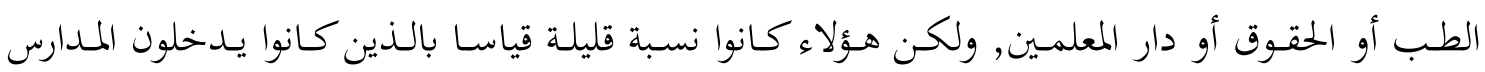
العسكرية من ابناء الطبقة الذين هم اكثر فقرا. وهذا هو السبب في ان الحكومة العراقية في بدايتها لم بحد بين المجتمع العراقي إلا عددا قليلا من خريجي المدارس العالية, ومن يستعرض اسماء رؤساء الوزارات الذين تولوا الحكم بين سنة 1923 وسنة 1941 نجد ان معظمهم كانوا ممن درسوا في المدارس العسكرية إنمئ. ويعكس قانون المعارف لسنة 1869 (بداية اهتمام الدولة العثمانية بانشاء المدارس الابتدائية في بغداد) مـدى تاثير النظام التعليمي العثماني بنظام التعليم الفرنسي وخاصة مـن ناحية اشراف الدولة على جميع المواضيع التدريسية في المدارس وتكوين مجلس المعارف, ولعل ابرز القوانين الفرنسية التي استند اليها نظام

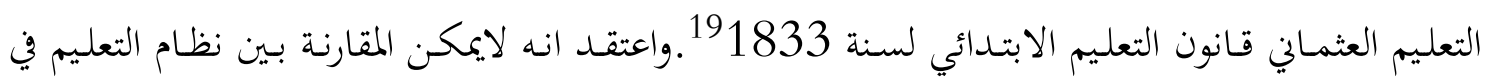
فرنسا والنظام التعليمي الذي تتبعه الدولة العثمانية في العراق الذي كان جل غايته تخريج موظفين لدوائر الدولة, كمـا اهـا لم تعطي المـدارس الابتدائيـة اهتمامـا جـادا, واكتفت بالكتاتيـب التي كانت تقوم بمهمـة التعليم الابتـائي, ويـذكر ان عـدد المـارس الرشـدية في منتصف القـرن التاسع عشـر لم يتجـاوز عن سـت مدارس فتط فيها 870 طالبا وهي نتيجة ضئيلة اذا ماقورنت بالخطط لوضع التعليم 20 21 2.تحليل واقع التعليم في العراق فئ 21 انصبت سياسة التعليم في العراق على بناء القدرات البشرية على أساس تربوي يسعى الى إعداد الاجيال المتعاقبة للتعامل مع الاوضاع الوطنية والاقليمية والدولية المتغيرة دائماً، في الوقت نفسه يجري التأكيد على الهوية الوطنية والقيم الاجتماعية والاخلاقية والثقافية. التزمت وزارتي التربية والتعليم العالي بتوفير فرص التعليم لجميع من هم في سن المدرسة إناثا وذكورا، وزيادة فرص الحصول المى التعليم الجيد في المستويات الأخرى مثل التعليم العالي بما فيه التعليم المهني والتعليم غير النظامي.

وعلى الرغم من ان العراق سجل إنجازات كبيرة في مجالات محوالأمية والتعليم منذ عقود مضت، وذلك عن طريق تخصيص موارد مادية وبشرية متزايدة لمحاربة الأمية وتعميم التعليم الابتـائي وتوسيع نطاق التعليم المتوسط والثانوي والعالي ، واتخذت تدابير إضافية لجسر الفجوات المتبقية بين الإناث والذكور في معدلات 
الالتحـاق وعلى جميع المستويات ولجميع أنواع التعليم، إلا ان العمليـة التربويـة والعلميـة وكمـا تعكسها بعض المؤشرات الاحصائية ظلت تعاني عموماً مـن تحديات واشكاليات تتطلب تدخلاً وجهداً مؤسسياً وبجتمعياً لمواجهة تلك التحديات والتخفيف من تداعياتما.

إن مؤشرات التعليم في العراق اليوم لاتزال متدنية وبعيدة نسبياً عن الاهداف المرجوة، مما يؤكد ان التعليمبما هو أداة للتمكين- لايزال قاصراً على مواجهة مشكلات الامية والتسرب من التعليم، وتحقيق المساواة بين الذكور والاناث في اكتساب التعليم في جميع مراحله.إذ لاتزال التفاوتات التعليمية بين الجنسين كذلك اختلالاته الجغرافية موجـودة. فالتفـاوت بين الذكور والإناث في الالتحـاق بالتعليم الابتـائي وبين المناطق الحضرية والريفية وبين المحافظات تتراوح مابين معدلات متدنية ومعدلات مرتفعة ، وهو مايشكل عقبة أمام تحقيق الهدف الثاني من الأهداف الإنمائية للألفية وهو تحقيق تعميم التعليم الابتدائي بحلول عام 2015. كما تنخفض نسب الالتحاق في التعليم المتوسط والاعدادي.

وين ظل النمو السكاني المرتفع وقصور الإمكانات المادية والبشرية والتقنية، بدأ الجانب الكمي للتعليم يتقدم

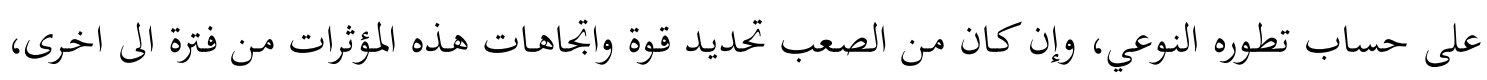
إلا أن الكثير مـن المعطيات والدلائل تشير اليوم إلى تراجعات أو اختلالات قـد ألمتت بالتطور التعليمي،

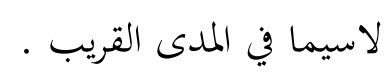
1- 1 الالتحاق في التعليم

استمرت الفجـوة بـين المراحل الثثلاث (الابتدائيـة والمتوسطة والاعداديـة) في معـدلات الالتحــاق في التعليم، إذ ان ماتستوعبه المرحلة المتوسطة، وفقاً لمؤشرات هذا المعدل، هو أقل مـن نصف مخرجات

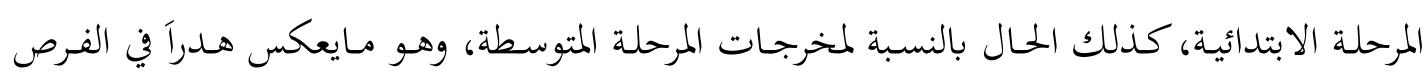
التعليمية بتلكؤ أكثر من نصف اعداد الطلبة في كل مرحلة من اجتيازها ضمن السقف الزمني المحدد.

$$
\text { أ-التعليم الابتدائي }
$$

لاتزال الثغرات قائمة في التعليم الابتدائي على الرغم مـ الاقتراب من تعميم هذا التعليم في انحاء كثيرة من العالم. وفي العراق لايزال طفل واحد على الاقل من أصل كل عشرة أطفال في سن التعليم الابتدائي خارج المدرسة. وحتى الاطفـال الملتحقين في المـارس يواجهـون مشكلات كثيرة منها مشـاكل بيئية واقتصادية واجتماعية، ولوجستية، تسهم جميعها في إبطاء عملية التعليم والتأثير في نوعيته وفي تخفيض معدل الالتحاق 
بالمدارس. وأكثر من يتأثر بهذا الوضع هي الفتاة، لأن عليها ان توفق بين الدراسة وواجبات أخرى فرضتها البيئة الثقافية والاقتصادية. سـجل الجهـــ التربـوي المبـذول خـلال السـنوات الدراسـية منـــ العـام 2005/2004 ولغايــة العـام

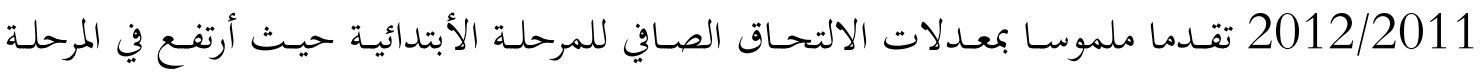
الأبتدائية للفئة 6-11 سنة من 86\% الى 92\%. ب-التعليم الثانوي ظل التباين قائماً على مستوى تقديم الخدمة التربوية، لاسيما في التعليم الثانوي، بين الحضر و الريف، وحسب النوع الاجتماعي، وفيما بين المحافظات. وتبرز تلك التباينات على أشدها في المرحلة الأعدادية سواء على مستوى نشـر التعليم، أي البنـاء المدرسي ( ويمكن قياسها بتبـاين نسب عـدد مـدارس المرحلة الدراسية منسوبا الى عدد المدارس للمرحلة السابقة لها ) أو على مستوى توفير متطلبات نوعية التعليم ( توفر المختبرات المدرسية و تشغيلها ، التباين في توزيع المعلمسين و المدرسين مـن حيث الخببرة ) وعـادة مـا تتركز تلك المتطلبـات في العاصـمة أو مراكـز المحافظـات، وقـد ضـيع هـذا الواقع فرصـا لتعليم و تأهيـل الشباب و أمكانية حصولم على فرص علمية أو تخصصات متقدمة في السلم التعليمي.

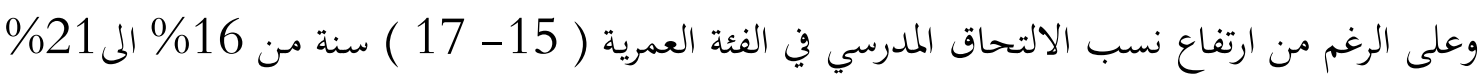
للاعوام 2005/2004 ولغاية العام 2012/2011، إلا ان الفجوة لاتزال كبيرة في هذا المجال. ويبدو ان هـا متـأت مـن التلكؤ الحاصل في المرحلة المتوسطة التي لم تحقق أي تقـدم فقـد ظل معـدل الألتحـاق

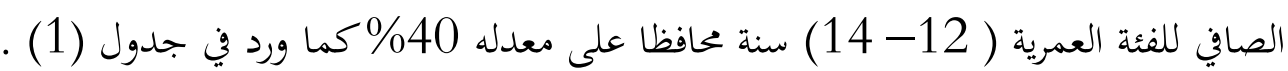
إن استمرار الفجوة بين المراحل الثلاث يعكس اختلالا بنيوياً واضحاً في منظومة البناء المعرفي. إذ أن ما تستوعبه المرحلة المتوسطة، وفقا للمؤشرات أعلاه، هي أقل من نصف مخرجات المرحلة الأبتدائية وكذا الأمر في المرحلة الأعدادية بالنسبة الى مخرجات المرحلة المتوسطة، وهذا يعني أن هناك هدراً في الفرص التعليمية بتلكؤ أكثر من نصف أعداد الطلاب في كل مرحلة من اجتيازها ضمن السقف الزمني المقرر لها، وهو ما يشكل ضغطا على الموازنة التربوية وخسارة لتخصيصات مالية من الممكن استثمارها في خلق فرص تعليمية 


\begin{tabular}{|c|c|c|c|c|c|c|}
\hline \multicolumn{7}{|c|}{ جدول يبين المؤشر التربوي (تلميذ/مدرسة) و (تلميذ/معلم ) في التعليم الابتدائي } \\
\hline & $2012 / 2011$ & & $2008 / 2007$ & & $2005 / 2004$ & \multirow{2}{*}{ 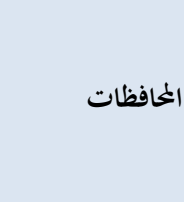 } \\
\hline معدل تلميذ / معلم & 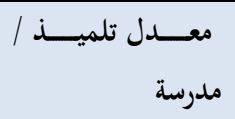 & معلم & معدل تلميذ / مدرسة & معدل تلميذ / معلم & مدرسة معل تلميـذ / مدر & \\
\hline 28 & 500 & 28 & 514 & 34 & 530 & 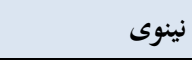 \\
\hline 15 & 329 & 14 & 350 & 19 & 464 & صلاح الدين \\
\hline 17 & 290 & 18 & 315 & 17 & 320 & كركوك \\
\hline 15 & 421 & 12 & 371 & 16 & 428 & ديالى \\
\hline 16 & 555 & 16 & 533 & 22 & 542 & بغداد/الرصافة 1 \\
\hline 26 & 785 & 24 & 800 & 26 & 714 & بغداد/الرصافة 2 \\
\hline 23 & 554 & 24 & 629 & - & - & بغداد/الرصافة 3 \\
\hline 11 & 474 & 12 & 449 & 18 & 580 & بغداد /الكرخ 1 \\
\hline 16 & 527 & 15 & 450 & 25 & 555 & بغداد /الكرخ 2 \\
\hline 17 & 676 & 16 & 661 & 21 & 830 & بغداد /الكرخ 3 \\
\hline 15 & 331 & 15 & 259 & 17 & 297 & الانبار \\
\hline 19 & 535 & 17 & 551 & 18 & 472 & بابل \\
\hline 18 & 502 & 16 & 476 & 17 & 386 & كربلاء المقدسة \\
\hline 20 & 494 & 19 & 484 & 22 & 479 & النجف الاشرف \\
\hline 16 & 448 & 16 & 467 & 36 & 413 & القادسية \\
\hline 18 & 317 & 15 & 302 & 21 & 367 & المثنى \\
\hline 17 & 367 & 16 & 363 & 15 & 626 & واسط \\
\hline 17 & 418 & 16 & 412 & 16 & 351 & ذي قار \\
\hline 14 & 351 & 12 & 335 & 20 & 428 & ميسان \\
\hline 23 & 490 & 22 & 475 & 23 & 407 & البصرة \\
\hline 19 & 464 & 18 & 456 & 21 & 473 & البجموع \\
\hline
\end{tabular}

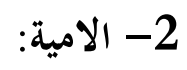

رغم الجهود الكبيرة التي بذلت في مجال محو الامية وتعليم الكبار، والتطور الواضح الذي عبر عنه انخفاض نسب الاميـة قبل عقدين مضـت، يلاحظ تراجع وتفـاوت في هذه الجهـود مـن حيـث اهميتها وحجمها واستمرارها ونتائجها. إذ باتت تشكل العائق الاكبر في منظومة البناء التربوي والمعرفي في العراق، بعد ان 
بلغ متوسط مـن هم بحالة أمي (22.9) من السكان وأن نسبة من اكتسب الحـد الأدنى مـ القراءة

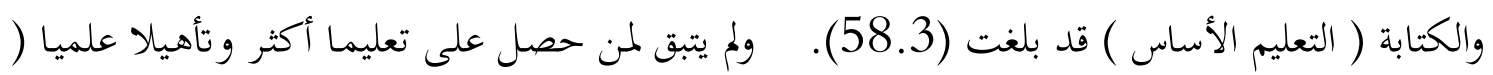

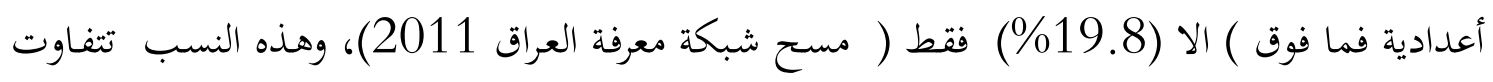

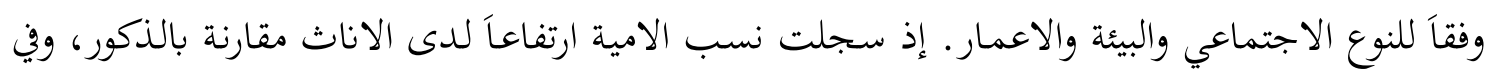

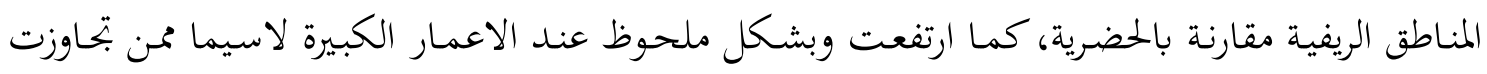

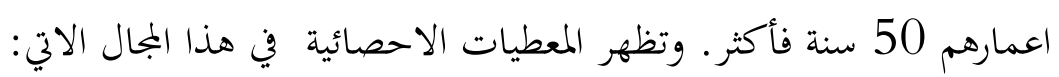

تظهر المسوح تفاوتاً في مستوى تقديم الخدمة التربوية في العراق، لهذا كان البون شاسعا في انتشار

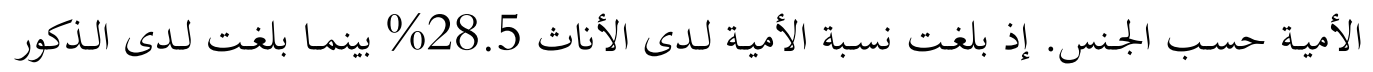

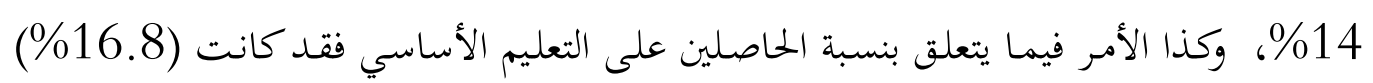
للأناث و (20.9\%) للذكور.

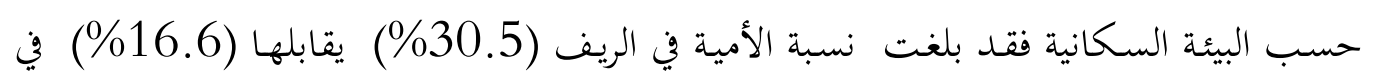

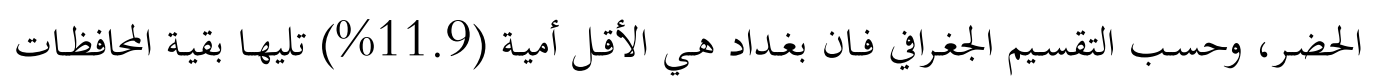

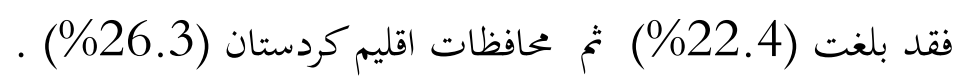

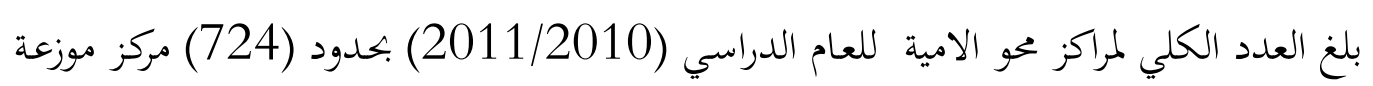

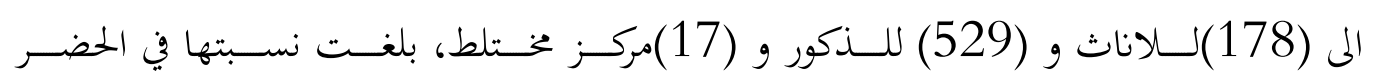

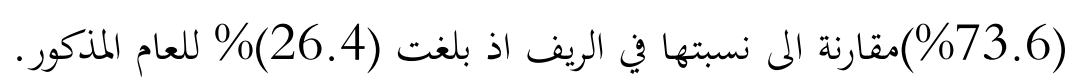

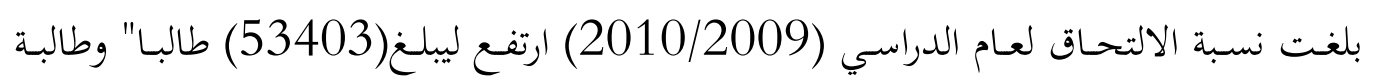

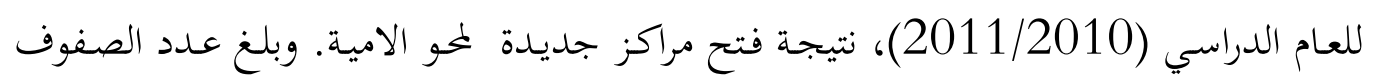

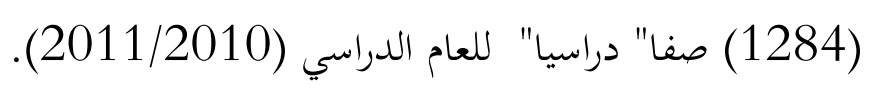

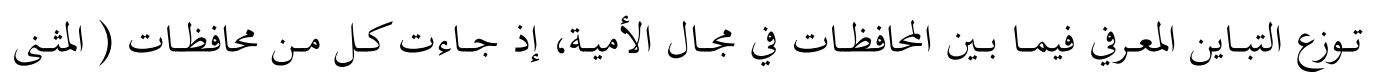

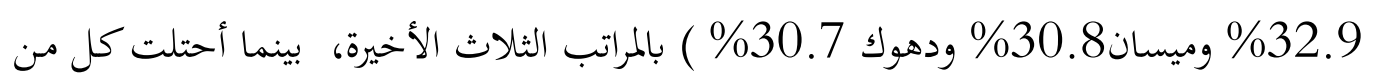
( بغداد 11.9\% وديالى 15.8\% وبابل 17.1 ) المراتب الثلاث الأول. 
سجلت محافظات ( دهوك 18.1\% والقادسية 18.4\% وميسان 18.5\% ) المراتب الأدنى

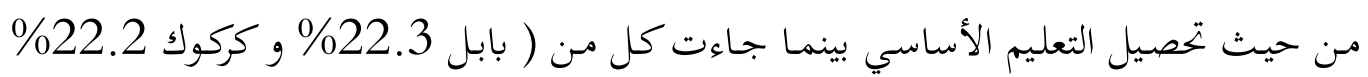

$$
\text { والانبار 22.1\% ) بالمراتب الثلاث الأول. }
$$

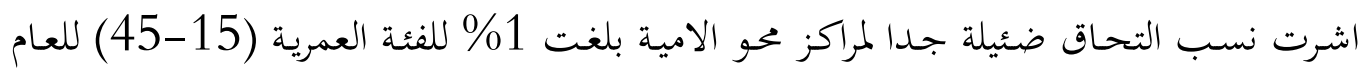

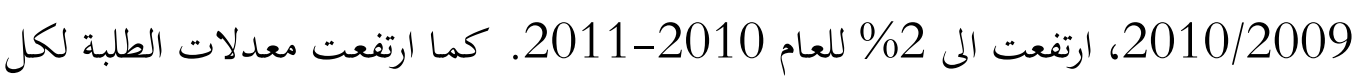
مركز محو امية من 44 طالب الى 73 طالب للاعوام اعلاه.

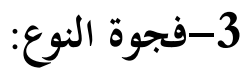

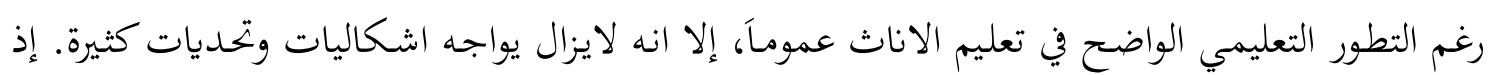

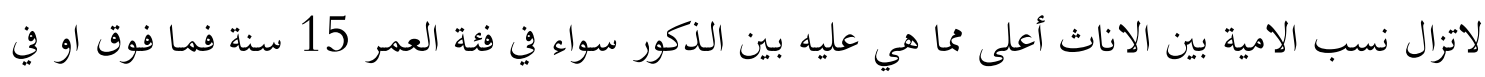

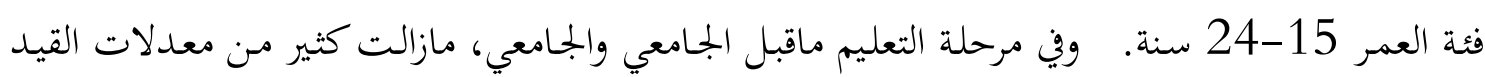
الاجمالية والصافية للأناث منخفضة مقارنة بمثيلاتما في كثير من دول العالم.

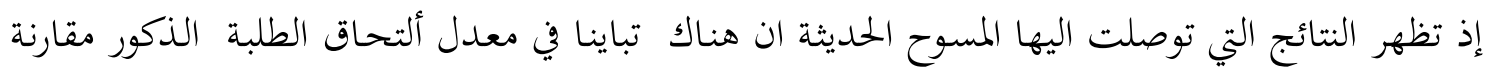

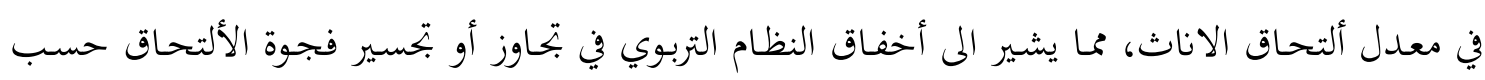

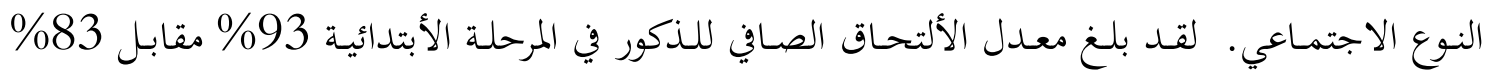

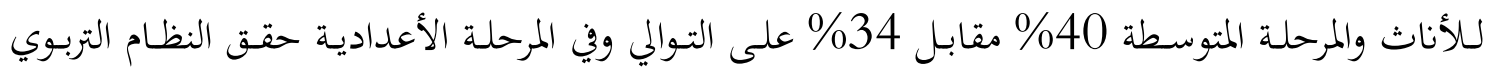

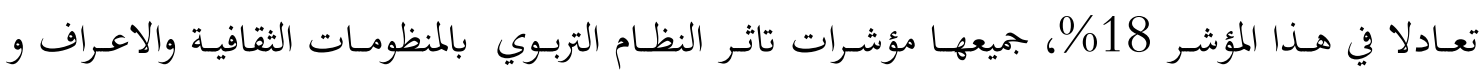

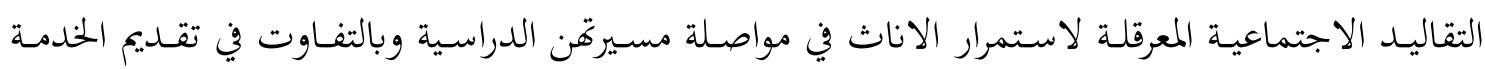

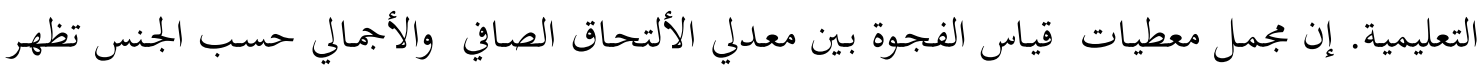

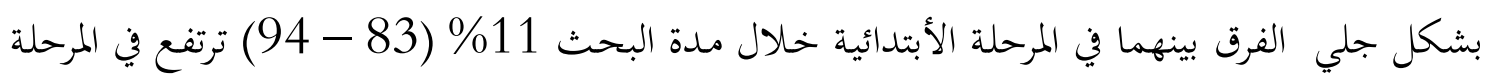

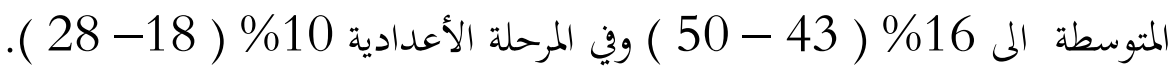

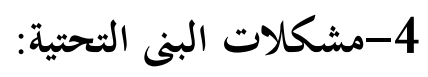

بلغت اعداد الابنية المدرسية (10451) أللعام الدراسي (2011/2010) ارتفعت الى (10658) بناية للعام (2012/2011). 
- بلــغ مقـــارالعجز في الابنيـة المدرسـية

(3762) بناية مدرسية للعام (2012/2011).

- هنـاك ازدواج ثنـائي في (5502) بنايـة

وازدواج ثلاثي في (609) بناية للعام الدراسي (2011/2010).

- هنـــــك (497) مدرســـــة طينيــــة

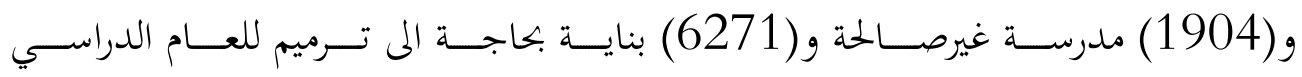

.(2011/2010)

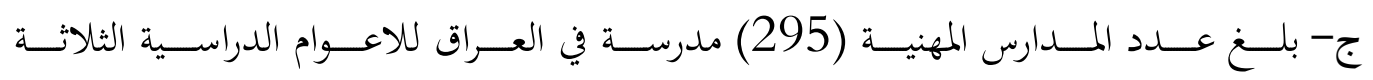

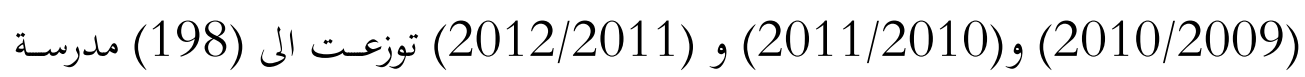

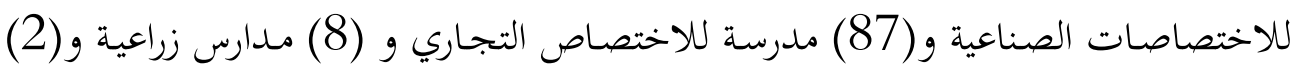

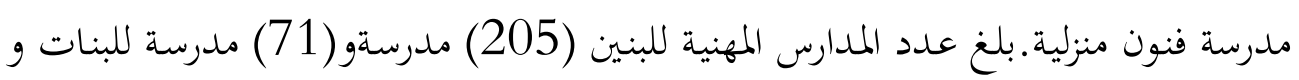
(18)مدرسة مختلطة

ح- تعاني (30\%) من الأبنية المدرسية من تدني كفاءة المرافق الصحية ومنظومة الماء الصالح

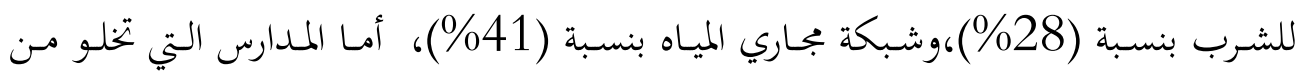

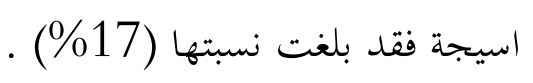

خ-عدم كفاءة الملاكات الفنية والمقاولين في تحقيق أداء كفوء والإفادة من التخصيصات المالية

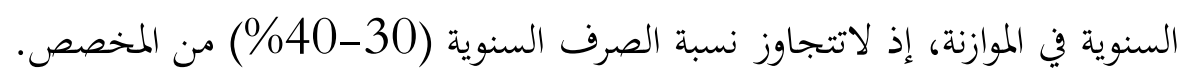

د- المخاطر الناجمة عن الاخطاء في التشييد مما يؤدي إلى تبديد الموارد وتعريض حياة التلاميذ

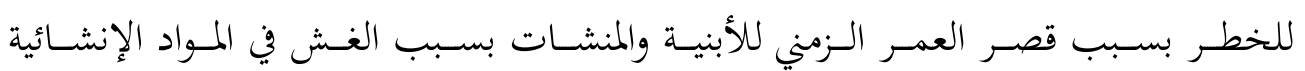

$$
\text { والتجهيزات وغيرها. }
$$

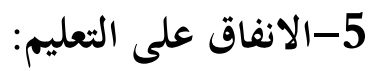


على الرغم من الزيادة المستمرة في نسبة الاتفاق على التعليم العام والعالي من الناتج المحلي الاجمالي ومـن الموازنة العامة للدولة التي خصصت (6.9\%) للتربية و (2.6\%) للتعليم العالي عام 2012، إلا ان ما تم تخصيصه لايكفي لتلبية المتطلبات الاساسية لتطوير البنى التحتية وتحسين البيئة الدراسية. وتمثل النفقات

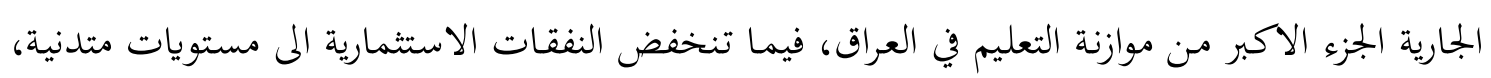

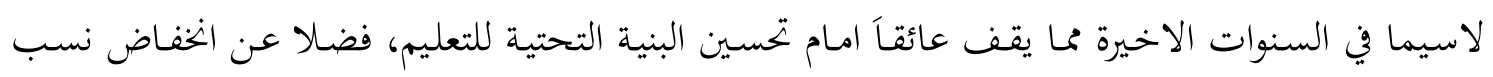

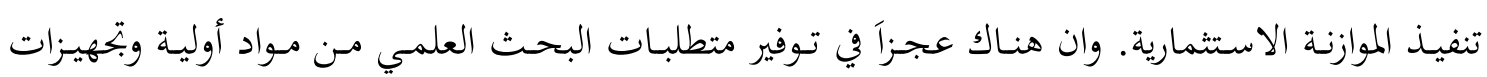
وحاسبات واجهزة مختبرية تخصصية.

وبالمقارنة مع البلدان الاخرى، لازال نصيب التلميذ الواحد من نفقات التعليم العام في العراق قليلة ، ومن ثم فان زيادة الانفاق العام على التعليم لاسيما الاستثمار في البنية الاساسية التعليمية مازالت حاجة ملحة. تبلغ نسبة الاموال المخصصة لقطاع التعليم للاعوام 2010-2012 حوالي 10\% من الموازنة العامة للدولة.

يشير واقع الانفاق الاستثماري في وزارة التربية الى الانخفاض النسبي للعامين 2011-2012 مقارنة بعام 2010، مقابل ارتفاع كبير في الانفاق الجاري للعامين الاخيرين.

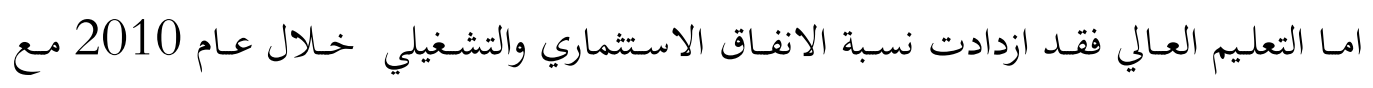
انخفاض واضح في نسبة المخصص للوزارة من الموازنة العامة خلال السنتين الاخيرتين، وكما هو موضح في الجدول ادناه. 
جـدول ( 3 ) يبين المبـالغ المخصصـة للتربية والتعليم العـالي مـ الموازنـة العامـة للأعوام 20102012

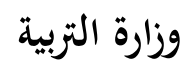

\begin{tabular}{|c|c|c|c|c|}
\hline العبائة المخص من من الموازنة & المجموع & الاستثماري & الجاري & السنوات \\
\hline 6.5 & 5544.444 & 500.000 & 5044.444 & 2010 \\
\hline 7.8 & 7583.005 & 450.000 & 7133.005 & 2011 \\
\hline 6.9 & $\mathbf{8 0 5 8 . 2 3 5}$ & 455.000 & 7603.235 & 2012 \\
\hline
\end{tabular}

وزارة التعليم العالي والبحث العلمي

\begin{tabular}{|c|c|c|c|c|}
\hline نسبة المخصـص مسن الموازنــة & المجموع & الاستثماري & الجاري & السنوات \\
\hline 3.0 & 2548.563 & 350.000 & 2198.563 & 2010 \\
\hline 2.7 & 2574.500 & 400.000 & 2174.414 & 2011 \\
\hline 2.6 & 3102.382 & 490.000 & 2612.382 & 2012 \\
\hline
\end{tabular}

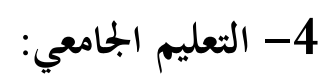

أ- بلغ عدد الجامعات العراقية الحالية ( 19) جامعة ما عدا الزيادة المقترحة بواقع (12) جامعة منها

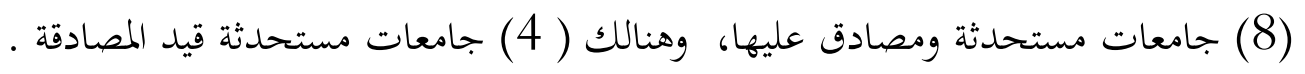


ب - بـــ عـدد الكليـات الحكوميـة (273) كليـة، عـدد الكليـات الأهليـة ( 45) للعـام الدراسي

2012/2011. وقد ظهر مؤشر اهتمام في المجال التقني، حيث بلغ عدد الكليات التقنية (16)

وعدد المعاهد التقنية (27)، وهناك (5) كليات تطبيقية قيد الاستحداث .

جدول رقم) (4) (2) (2) (2)

\begin{tabular}{|c|c|c|c|c|}
\hline الملاحظات & عدد التشكيلات & علدد التشكيلات & نوع التشكيل & ت \\
\hline & جامعة 12 استحداث 12 & 19 & الجامعات الحكومية & 1 \\
\hline بواقع زيادة 24 كلية & 273 & 249 & الكليات الحكومية & 2 \\
\hline بواقع زيادة 23 كلية & 45 & 22 & الكليات الاهلية & 3 \\
\hline تمبيقة اســــتحداث 5 كليـــــات & 16 & 16 & الكليات التقنية & 4 \\
\hline لم يتم تحقيق زيادة & 27 & 27 & المعاهد الفنية & 5 \\
\hline
\end{tabular}

ت - تقدر نسبة القبول في الجامعات العراقية بنحو 14\%، وهي اقل بكثير من المعدلات العالمية التي

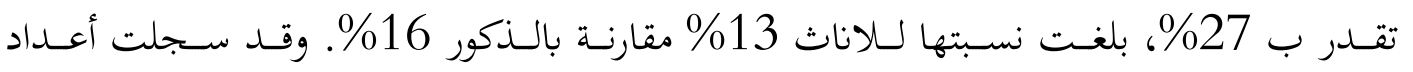

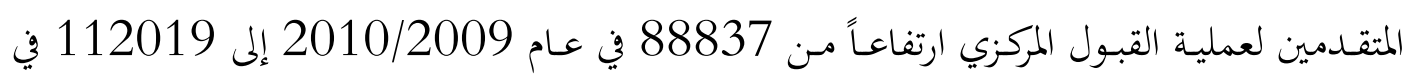

$$
\text { عام 2011/2010 ( زيادة بنسبة 26\%). }
$$




\section{التوصيات والمقترحات}

1.نرى ضرورة الاهتمام بالقاعدة الاساسية المتمثلة بالمعلم الذي يعيش منذ عشرات السنين في الوطن العربي, وفي العراق بحالة متدنية من حيث المستوى المعاشي, واستخدامه لوسائل التعليم المتخلفة مع الطلاب باستعمال العصا والضرب المبرح والتي ورثها المعلمين من الملالي . 2. الاهتمام بموضوع اللغة الانكليزية للطلاب وبالذات للطلبة العراقيين الذين يعانون من اساسات هشة وضعيفة سببها سوء التخطيط وجهل الكثير من القائمين على وزارة التربية والتعليم. 3.انحدار مستوى التعليم نتيجة لسياسات الدولة العثمانية في القرن التايع عشر وبداية القرن العشرين نتيجة لاهتمام الدولة العثمانية بمصالحها العسكرية والسياسية, ولو اهتمت بالتعليم كما اهتم به محمد علي باشا في مصر لكان للعراق شان اخر. 4.تسييس التعليم منذ الاحتلال البريطاني للعراق إلى الاحتلال الامريكى وخضوعه لاهواء المحتلين ولسياسات الحكام. 5.تراوح المناهج الدراسية مكاها ولم تستطع وزارة التربية حتى اليوم من كتابة التاريخ والدين للمدارس

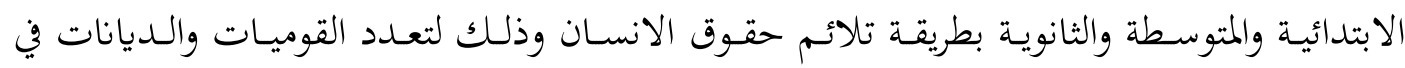

$$
\text { العراق وعدم انصهارها في بوتقة وطنية. }
$$

6.عدم تغليب مصلحة الوطن على مصلحة الشخص بالنسبة للقائمين على التعليم واخضاع التعليم

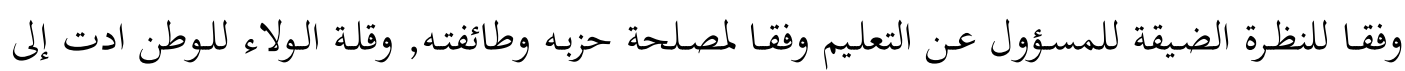

$$
\text { بروز ولاءات اخرى جرت التعليم إلى الخضوع لسياسات محلية ودولية اخرى. }
$$

7. التلاعب بالمنـاهج ايضـا وفقـا لاهـواء القـائم على التعليم وينتج عن ذلك عـدم استقرار تعليمي للطالب, اضافة إلى الشعور بعدم الاستقرار والانسيابية في التعليم. 8.نتيجة لعدم استقرار العراق ولخوضه العديد من الحروب والاحتلالات المتعاقبة وللسياسات الغير صحيحة للحكام برزت كثير من الحالات الغير صحية في النظام التعليمي كاللجوء إلى الدور الثالث في الامتحانات وفي بعض السنوات الدور الرابع ونظام التحميل والعبور , ادى إلى خلل وضعف في المستوى التعليمي , وادى إلى بروز ظواهر الغش وحالات الفساد التعليمي ووصول كوادر ضعيفة إلى مستويات عليا 
في العملية التعليمية, كل ذلك يستوجب وقفة جادة ومتميزة وحقيقية للنهوض بالعملية التعليمية من جديد في العراق والوطن العربي, لغرض النهوض بواقع التعليم من جديد بعيدا

1 انتوني غدنز, علم الاجتماع ترجمة وتقديم د.فايز الصياغ, مركز دراسات الوحدة العربية, بيروت, ط1, 2005, ص541

2 الامم المتحدة و البنك الدولي , التقديرات المشتركة لاعادة الاعمار , 2003 , ص19 3 د. محمد محمود الجوهري المدخل إلى علم الاجتماع, دار المسيرة للنشر و التوزيع و الطباعة,ط1, 2010, ص231 4 د.مناور فريح حداد, بحث النمو الاقتصادي وو اقع القوى العاملة في الاردن, مجلة اربد للبحوث و الدراسات,

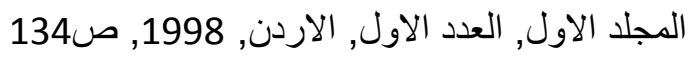
5 انتوني غدنز, علم الاجتماع, مصدر سابق, من ص542_ص544

http// ejabat.google.com 6 تجربة مصر في محو الامية

7 ندوة عالمية بحثت ملفات محو الامية في مصر و الخطط المستقبلية لمواجتها على الر ابط forum.amrkhaled.net/showthread

http //

8 مفيدة حمود ابراهيم, ازمة التربية في الوطن العربي, عمان, دار مجدلاوي, 1999, ص32 9 فؤاد نصحي, التخطيط التربوي على مستوى الوطن العربي ,بيروت, دار الكتاب اللبناني , 1978, ص43 10 محمد علي مداح, مشكلة الامية ومستقبل التنمية في الوطن العربي, بيروت, المؤسسة العربية للار اسات والنشر, 1993, صحمب مداح 11 كمال مظهر احمد, النهضة, بغداد, 1979,ص60 12 فاضل عبد الواحد علي, سومر اسطورة وملحمة, بغداد, 2000, ص57 13 د. احمد جودة, تاريخ التربية والتعليم في العر اق و اثره في الجانب السياسي, مؤسسة مصر مرنضى للكتاب, بغداد, 2010, صد 14 د. عبد الو هاب حميد رشيد, العر اق المعاصر , دار المدى للثقافة و النشر , دمش, ط1, 2002, ص250 


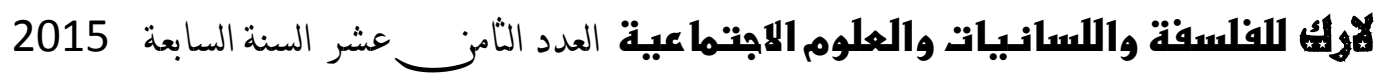

15 تثارلز تريب, صفحات من تاريخ العراق, ترجمة زينه جابر إدريس, الدار العربية للعلوم, بيروت, ط1,

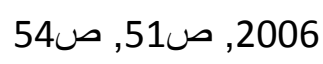

16 د.احمد جودة, تاريخ التربية والتعليم في العر اق, المصدر السابق, ص83 17 علي الوردي, لمحات اجتماعية من تاريخ العراق الحديث, ج2, بغداد, 1971, ص261 18 د.احمد جودة, تاريخ التربية والتعليم في العراق, المصدر السابق, ص38_39 19 ابر اهيم خليل احمد, تطور التعليم في العراق(1869_1932), البصرة, 1982, ص33وص36 20 21 من خطة التنمية الوطنية(2013_2014) 


\begin{tabular}{|c|c|c|c|c|c|c|c|c|c|c|c|}
\hline $12 / 2011$ & & & & & $08 / 2007$ & & & & & $05 / 2004$ & \\
\hline المدارس & / معلم تلميذا & مدرسدة تلميـــ / & التلامذة & المعلمين & المدارس & معلم معل تلميذ / & مدرسدة تلميذ / معا & التلامذة & المعلمين & المدارس & \\
\hline 639 & 28 & 514 & 288760 & 10253 & 562 & 34 & 530 & 280305 & 8191 & 529 & نينوى \\
\hline 304 & 14 & 350 & 83949 & 5968 & 240 & 19 & 464 & 125349 & 6530 & 270 & صلاح الدين \\
\hline 442 & 18 & 315 & 115382 & 6395 & 366 & 17 & 320 & 100552 & 6036 & 314 & كركوك \\
\hline 285 & 12 & 371 & 89298 & 7451 & 241 & 16 & 428 & 93351 & 5935 & 218 & \\
\hline 1015 & 64 & 1962 & 590177 & 27955 & 89 & $\begin{array}{r}48 \\
-\end{array}$ & 1256 & 507604 & 21223 & 828 & فهـ \\
\hline 648 & 43 & 1560 & 303526 & 21580 & 601 & 64 & 1965 & 366538 & 17020 & 583 & كرخ \\
\hline 457 & 15 & 259 & 127817 & 8545 & 493 & 17 & 297 & 93726 & 5475 & 316 & الانبار \\
\hline 302 & 17 & 551 & 141589 & 8300 & 257 & 18 & 472 & 118427 & 6633 & 251 & بابل \\
\hline 265 & 16 & 476 & 114221 & 7318 & 240 & 17 & 386 & 88086 & 5198 & 228 & كربلاء المقدسة \\
\hline 340 & 19 & 484 & 146054 & 7516 & 302 & 22 & 479 & 126067 & 5622 & 263 & النجف الاشرف \\
\hline 283 & 16 & 467 & 114432 & 7257 & 245 & 36 & 413 & 92108 & 2559 & 223 & القادسية \\
\hline 176 & 15 & 302 & 48397 & 3130 & 160 & 21 & 367 & 45864 & 2191 & 125 & المثى \\
\hline 321 & 16 & 363 & 100613 & 6220 & 277 & 15 & 626 & 85121 & 5661 & 136 & واسط \\
\hline 468 & 16 & 412 & 173419 & 10530 & 421 & 16 & 351 & 144072 & 9003 & 411 & ذي قار \\
\hline 343 & 12 & 335 & 94218 & 7568 & 281 & 20 & 428 & 78686 & 3900 & 184 & ميسان \\
\hline 720 & 22 & 475 & 301879 & 13887 & 635 & 23 & 407 & 253843 & 10961 & 623 & البصرة \\
\hline 7008 & 18 & 456 & 2833731 & 159873 & 6220 & 21 & 473 & 2599699 & 122147 & 5502 & المجموع \\
\hline
\end{tabular}

